\title{
A Little Mathematics in an Undergraduate Cell Biology Course Jonghoon Kang ${ }^{1 *}$ and Steven M. Thompson ${ }^{2}$
}

${ }^{1}$ Department of Biology, Valdosta State University, Valdosta, GA 31698, USA

${ }^{2}$ Biolnfo4U, 2538 Winnwood Circle, Valdosta, GA 31601, USA

\begin{abstract}
Mathematics and other quantitative sciences are becoming more critical in biology education and research than ever before. However, in our opinion, not enough academic institutions in the USA are ready to embrace this new trend. In this article, we suggest how we can improve the current reality of unpreparedness on the basis of our direct experience rather than ideological arguments. Specifically we propose to consider three aspects in education: resources, culture, and global efforts. We hope that Biomolecules as a new journal in biomolecular science will serve as an excellent medium to poster the ideas.
\end{abstract}

Keywords: Undergraduate; Curriculum; Cell biology; Mathematics; Textbooks

\section{Main Text}

The fact that mathematics, as well as other quantitative sciences such as physics, plays a critical role in biology education and research is becoming obvious [1]. This trend is also reflected in the view of the American Society for Cell Biology [2] and the National Research Council [3]. Furthermore, many excellent textbooks are being published in line with this view [4]. However, we have found that most of the mathematical topics introduced in such quantitative biology textbooks are overly advanced for the majority of biology students, who are too poorly prepared in mathematics to sufficiently comprehend the content [5].

We, as present and past biology faculty members at state universities, have observed that many of our students get lost or confused in class when introduced to terms such as "exponential" or "logarithmic". This has happened to us at all course levels, beginning through advanced, undergraduate and graduate. These are basic, but very important mathematical concepts, that should have been learned in college algebra courses. Although we do not have any objective data, we expect that this poor or incorrect quantitative reasoning might be a common, rather than exceptional, phenomenon in the biology academic community throughout the USA. So, although the desirable and appropriate goal of developing biology into a quantitative science exists at large, the reality is that many of us are not quite ready yet to embark on the journey.

In our opinion, this reality is due to a false perception that biology, of all the 'hard' sciences, requires the least amount of mathematics. This perception affects both the students entering biology courses, which leaves them under-prepared for the content, as well as the faculty teaching those courses, as it may have been what initially guided them into biology in the first place. In fact, one of us, Thompson, is somewhat guilty of this himself, even though he has taught bioinformatics professionally for over two decades - this has required a lot of catch-up work on his part. Two direct consequences result from this misperception: 1) a lack of proper mathematical skills in both students and professors in the biology fields, and 2) a strong reluctance in both parties to think quantitatively. The repercussions are severe. Many students are very good at the memorization of facts. However, it will be disastrous for the students themselves, as well as for society as a whole, to keep producing students who can memorize facts well, but have no idea of how to critically analyze those facts.

My cell biology course for undergraduates at Valdosta State Uni- versity uses Essential Cell Biology [6]. This textbook has many outstanding features and is considered a standard in undergraduate cell biology courses [7]. Page 498 of this text shows a table of the relative volumes of the major organelles in a liver cell with an explanation stating, "On average, the membrane-enclosed organelles together occupy nearly half the volume of a eukaryotic cell...". I was curious about this statement and suspected that the data might be able to be described by a simple equation. Therefore, I plotted the data values in Excel and tested several simple equations. I found that the volumes of the first six largest compartments could be described successfully $\left(R^{2}: 0.996\right)$ by an exponential function (Figure 1A). The best fitting equation suggests that the volume $(V)$ of the first six largest compartments could be described by an exponential decay function of rank order $(r)$. Or more succinctly,

$$
V=a \exp (b r) \text {, }
$$

where $\mathrm{a}$ and $\mathrm{b}$ are fitting parameters. I then linearized the exponential function hoping that I could teach the technique to my class. The linearized form is $y=b r+n$, where $y$ is $\ln V$ and $n$ is $\ln a$ (Figure 1B). The next day I introduced the analysis to my students. Several of them appeared confused, as to be expected, but some actually seemed to follow the analysis and, encouragingly, showed interest in it.

We would like to point out four observations here based on Kang's experience. The first is to actually demonstrate a positive attitude toward quantitative approaches in the study of biology to your students through practice, and not just preach it in lecture. This can be critical in motivating them to appreciate the importance of quantitative approaches, and it may change their perception of biology such that they will realize that they need a certain degree of mathematics skill to really comprehend biology. Secondly, this type of experience provides opportunities to teach mathematical techniques, this time the linearization of a nonlinear equation, which is an important concept in many areas of biology, for example, in the linearization of the Michaelis-Menten enzyme kinetics equation [8]. Of course, it is a very basic technique,

*Corresponding author: Jonghoon Kang, Department of Biology, Valdosta State University, 1500 N Patterson, Valdosta, GA 31698, USA, Tel: 1-229-333-7140; Fax: 1-229-245-6585; E-mail: jkang@valdosta.edu

Received March 06, 2012; Accepted March 19, 2012; Published March 24, 2012

Citation: Kang J, Thompson SM (2012) A Little Mathematics in an Undergraduate Cell Biology Course. J Biomol Res Ther 1:e103. doi:10.4172/2167-7956.1000e103

Copyright: (c) 2012 Kang J, et al. This is an open-access article distributed under the terms of the Creative Commons Attribution License, which permits unrestricted use, distribution, and reproduction in any medium, provided the original author and source are credited. 
but it was new to many of them or was something forgotten. Third, this sort of pedagogy might allow students to realize that the mathematical skills they already have can be applied to the quantitative analysis of biological phenomena. This is important because it can provide relevance to the mathematics courses that they have taken, such as college algebra, trigonometry, pre-calculus, statistics, and calculus, toward the study of biology. Fourth, this type of simple analysis may have a practical or scientific implication. For example, one can test the result for its generality by applying the analysis to other cell types. If the exponential feature is general, it would be interesting to examine the sensitivity of the fitting parameters, $a$ and $b$, to different cell types or to the same cell type at different physiological conditions.

So, what should or can we, as educators of college biology, do to achieve the goal of making biology a quantitative science, versus the gloomy reality that many of us know we now have? In our opinion, we have to consider three things: resources, culture, and global efforts. By resources we mean faculty and textbooks. As we mentioned, not all biology faculty members are comfortable in basic mathematics. We as faculty members need to educate ourselves before we teach our students. In fact, there is nothing wrong in learning something important. As a scientist we have learned new experimental techniques throughout our career. Biology textbooks need to be more quantitative in content. Of course, there are many biology textbooks that do use advanced mathematics [4]. However, they are not suitable for many typical biology students. We suggest a level of quantitative analyses in textbooks that fits the basic mathematic skills that most biology undergraduate students usually have as a part of their curricula requirements ranging from college algebra to calculus. For example, the table and verbal explanation in Essential Cell Biology referred to above might be replaced or supplemented by one of the figures (Figure 1A or Figure 1B) and the corresponding equation, respectively. This may be more effective than the table because graphs can deliver quantitative insight much more clearly [9]. In that sense, Phelan's forthcoming textbook [10], which will emphasize the interpretation and critical analysis of graphs, is quite welcome. Culture is the second component that needs to be considered. Around 100 years ago chemistry was in transition from a qualitative to a quantitative science; the scientists of the new frontier confronted an enormous opposition from the main stream. However, this quantitative trend developed and eventually turned out to be one of the most essential fields in chemistry, that of physical chemistry [11]. Biology department curriculum committees or any other authorities in charge of curriculum should embrace this point. As an example, biophysics is a quantitative biological subject, and we predict that its relative importance to biochemistry, a well-established biological discipline, will grow exponentially and reach $20 \%$ by the year 2020 [1]. Biology department of Valdosta State University has recognized this point and is one of few institutions in Georgia to offer biophysics at undergraduate level. If we do not take action now, we will produce students without competitiveness on the world market by that time. Finally, the science research community should play a pivotal role in this entire process. Research and education are not two separate entities, but should rather intertwine as two closely related sides of the same coin. One direct way the research community can assist in this process would be the construction and maintenance of a relational database that harbors bibliographic and scientific information from research publications that contain mathematical analyses of biological problems. This could be as beneficial to future biology textbook writers and other biology educators as the quantitative three-dimensional protein database (PDB) has been for so many researchers. We hope that this journal Biomolecules
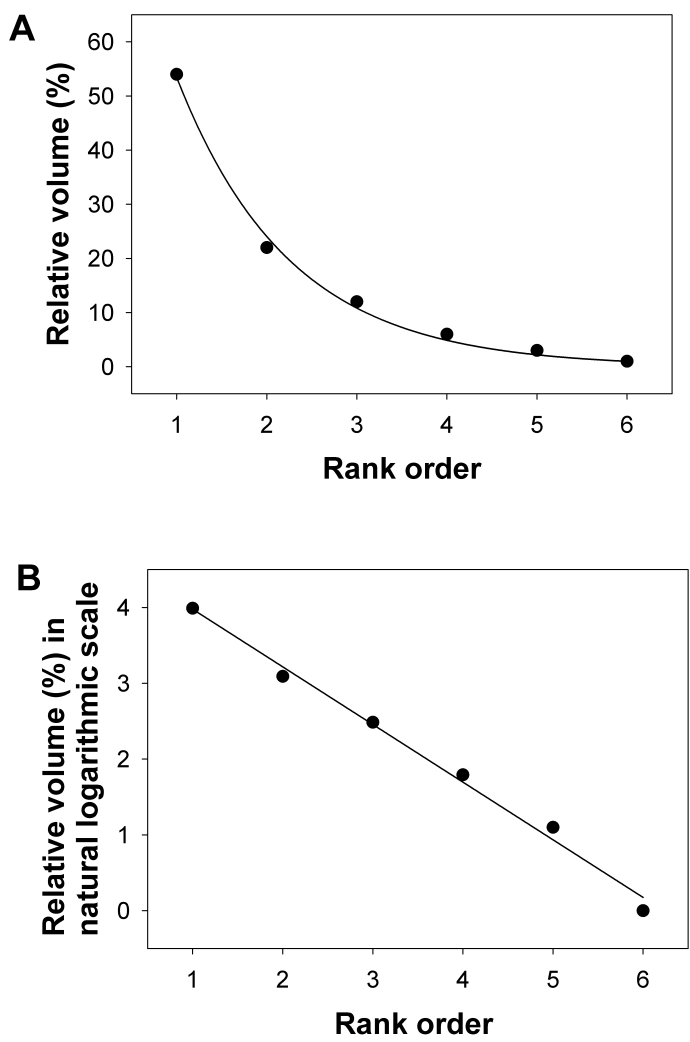

Figure 1: Exponential $(A)$ and linear $(B)$ fitting of the relative volumes of the major organelles in a liver cell as a function of rank order. The first six largest compartments are cytosol, mitochondria, endoplasmic reticulum, nucleus, golgi apparatus, and peroxisomes in a descending order. Fitting equations in (A) and (B) are $V=118.8 \exp (0.8 r)$ and $y=0.8 r+4.74$, respectively. Their $R^{2}$ values are $0.996(A)$ and $0.992(B)$. Curve fitting was performed using SigmaPlot (version 11, Systat Software Inc, San Jose, CA).

will be an excellent medium to poster the ideas presented in this article.

\section{Acknowledgement}

$\mathrm{JK}$ is a recipient of Reassigned Time from Valdosta State University. The content in this letter is not necessarily the view of Valdosta State University. The authors have no potential conflicts of interest.

\section{References}

1. Kang J, Purnell CB (2011) Implications for undergraduate education of two interdisciplinary biological sciences: biochemistry and biophysics. CBE Life Sci Educ 10: 111-112.

2. American Society for Cell Biology (2012) CBE-Life Sciences Education Instructions for Authors.

3. National Research Council (2003) Committee on Undergraduate Biology Education to Prepare Research Scientists for the 21st Century, Board on Life Sciences, Division of Earth and Life Sciences, BIO 2010: Transforming Undergraduate Education for Future Research Biologists. National Academies Press Washington, DC

4. Phillips R, Kondev J, Theriot J (2008) Physical Biology of the Cell. Garland, New York.

5. Bialek W, Botstein D (2004) Introductory science and mathematics education for 21st-Century biologists. Science 303: 788-790.

6. Alberts B, Bray D, Hopkin K, Johnson A, Lewis J, et al. (2009) Essential Cel Biology. (3rd edn), Garland, New York.

7. Konieczko EM (2009) Hello Old Friend, My How You've Changed! CBE Life Sci Educ 8: 167-168. 
Citation: Kang J, Thompson SM (2012) A Little Mathematics in an Undergraduate Cell Biology Course. J Biomol Res Ther 1:e103. doi:10.4172/21677956.1000e103

Page 3 of 3

8. Crowe J, Bradshaw T (2010) Chemistry for the Biosciences. (2nd edn), Oxford University Press, New York.

9. Few S (2009) You See It: Simple Visualization Techniques for Quantitative Analysis. Analytics Press, Oakland, CA.
10. WH Freeman (2012) What is Life? With Physiology \& Prep-U by Jay Phelan.

11. Servos JW (1996) Physical Chemistry from Ostwald to Pauling: The Making of a Science in America. Princeton University Press, Princeton, NJ. 